\title{
The Relationship Of Family Support With The Liveliness Of The Following Gymnastics In Patients With Diabetes Mellitus Type Duadi Club Prolanis Diamen Barigas BPJS Office Palangka Raya
}

\author{
Untung Halajur1*, Sri Widya ${ }^{2}$, Aida Kusnaningsih ${ }^{3}$ \\ 1,2,3 Jurusan Keperawatan Program Studi Sarjana Terapan, Poltekkes Kemenkes RI Palangka Raya Jalan George Obos \\ No. 30-32 Palangka Raya, Indonesia \\ * Corresponding author: \\ Email: halajuruntung@gmail.com
}

\begin{abstract}
Physical exercise is one of the pillars of diabetes management that needs to be cultivated, because there are many benefits that can be felt by people with DM. The number of benefits that can be felt by patients with DM, it is very necessary activeness of DM patients in doing one gym gymnastics. Activity of DM patients can also be influenced by several factors one of which is family support. This study aims to determine whether there is a relationship of family support with the activity of following gymnastics in people with diabetes mellitus type two. Thisused study observational research Cross Sectional. Instruments include family support questionnaires and liveliness forms. The population in this study were members of Club Prolanis Diamen Barigas BPJS Office Palangka Raya who experienced DM and samples in the study were two types of DM patients who followed the gymnastics activities as much as 30 respondents using sampling technique that is total sampling. Univariate analysis using frequency distribution table and bivariate analysis usingtest Chi-Square. The results showed that there was a significant correlation between family support and activeness following gymnastics in patients with type 2 diabetes mellitus At Club Prolanis Diamen Barigas BPJS Office Palangka Raya, with the result of statistical test of continuity correction known that significance $p$ value of 0,046 with $\alpha<(0.05)$. There is a relationship between family support and active follow gymnastics in patients with type 2 diabetes mellitus at Club Prolanis Diamen Barigas BPJS Palangka Raya.
\end{abstract}

Keywords : Diabetes mellitus, Family Support, Activity

\section{INTRODUCTION}

Non-communicable diseases (NCDS) become the main cause of death globally. Deaths PTM according to the World Health organization the WHO, is expected to continue increasing around the world. The largest increase will occur in the countries of the middle and poor. More than two-thirds (70\%) of the global population will die from non-communicable diseases such as cancer, heart disease, stroke and diabetes (Data Health Information, 2012). Diabetes mellitus (DM) is a health disorder in the form of a collection of symptoms caused by an increase in blood sugar levels due to a deficiency or insulin resistance (Bustan, 2007:100). The incidence of DM based on the epidemiological studies showed a trend of increasing both in the world and in Indonesia. The incidence of DM in the world in 2013 amounted to 382 million people and by 2035 that number will increase to 592 million people, and estimated from 382 million people that 175 million of whom have not been diagnosed, so threatened develop progressive complications without realizing it and without prevention (Kemenkes RI, 2014). Meanwhile, the data presented by the International Diabetes Federation (IDF) predicts an increase in the number of people with DM in Indonesia from 9.1 million in 2014 to 14.1 million by the year 2035 (Perkeni, 2015). The province of Central Kalimantan are on the order of twelve of the thirty-four Provinces in Indonesia with the proportion of patients with DM at the age of $\geq 15$ years (the Data and Information Center Health AFFAIRS, 2014). 
The Incidence of DM in the Province of Central Kalimantan in 2015 was ranked into five of the ten common diseases with the number 5.137 case (Dinkes Provinsi Kalimantan, 2015).DM if not handled properly, can be bad. A result that will occur can be in the form of damage to various body systems, especially the nerves and blood vessels, which increases the risk of heart disease and stroke, neuropathy (nerve damage) in the feet increases the incidence of foot ulcers, retinopathy diabetikum, renal failure, and the risk of death is doubled than non-diabetics (Kemenkes RI, 2014) . Bad effect of DM can be prevented and overcome with good management. The management of DM can be done with four pillars, namely, meal planning, physical exercise, management, pharmacological, and counseling. (Waspadji, 2009:36-44). Management of DM with the four pillars is an effort to control diabetes and prevent complications of diabetes mellitus. Physical exercise is one of the pillars of the management of diabetes in addition to meal planning use of drugs, and counseling so that physical exercise need to be cultivated. Physical exercise is recommended for people with diabetes is a type of aerobics such as walking, running, climbing stairs, bike, jog, and gymnastics. People with diabetes are encouraged physical exercise regularly three to four times a week for thirty minutes (Sukardji, 2009:285).

In addition, the benefits that can be felt by patients with DM type two if you do the sports regularly, i.e. increase and decrease in blood glucose levels, prevent obesity, play a role in addressing the possibility of the occurrence of complications atherogenic, disorders of blood lipids, increased blood pressure, hypercoagulation of the blood. These circumstances reduce the risk of Heart disease koriner (CHD) and improve the quality of life of diabetes with increasing work ability and also give you an advantage psychologically. (Elias, 2009:290). There are many benefits that can be felt by patients with DM, it is very necessary liveliness of patients with DM in doing sports. The liveliness of the patients with DM can also be influenced by several factors, one of which is the support of the family. Research Vivin (2012) shows there is a relationship of family support with the level of activeness in following the exercises in elderly posyandu "Caring Human" with a value of $\mathrm{x} 2$ count $=46,854$, and p-value $=0,000(<0,05)$. Research Eko et al $(2010)$ show that there is a relationship between family support to the participation of the elderly exercise, the results obtained test Continuity Correction with significancy $=0,030$ at $\mathrm{a}=0.05$.

A preliminary study conducted by researchers at the Office of BPJS Palangka Raya, obtained data on the number of participants Prolanis Club Diamen Barigas BPJS Office Palangka Raya experiencing DM as much as thirty-eight people and hypertension as much as thirty-two people. Participants Prolanis experiencing DM on the club that is patients with diabetes mellitus type two. The researchers also interviewed the caretaker of the Club Gymnastics that gymnastics is carried out twice a week every Tuesday and Friday at 05.30-06.30 WIB. See from his presence as gymnastics events took place, only about thirty members who attend the activities of gymnastics. In an interview with the board of Club gymnastics obtained information that, the members of the Club gymnastics indeed not everything is routine and actively participate in gymnastics activities such. The above phenomena suggest that the importance of Diabetes Mellitus patients in performing physical activity regularly, it is necessary to be aware about the level of activeness of patients with DM in doing sports. In connection with the foregoing, the researcher interested to conduct research about one of the factors that affect the inactivity of patients with diabetes mellitus type two in doing physical activity that is "the Relationship of Family Support With the Liveliness of Following the exercises In Patients with Diabetes Mellitus Type Two In the Club Prolanis Diamen Barigas BPJS Office Palangka Raya".

\section{METHODS}

This research is an observational research using cross sectional study design. A cross sectional study is a type of survey that observes an object of study both one and several variables, by way of collecting data in a time like this. The independent variable in this research is the support of the family and the dependent variable in this research is the liveliness of following the exercises. This research is conducted in the Office of the BPJS Palangka Raya with the time of the study at the start of the month of April - May 2018. The population in this study are members of the Club Prolanis Diamen Barigas BPJS Office Palangka Raya 
experienced DM and samples in the study were patients with DM type two which follow the activities of gymnastics as much as 30 respondents by using purposive sampling yaitu total sampling. Instrument in this research is a questionnaire of family support and form liveliness.

III. RESULTS OF THE RESEARCH

Table 1. Frequency distribution of Respondents By Family Support $(\mathrm{n}=30)$

\begin{tabular}{ccc}
\hline Family Support & Number & \% \\
\hline Good & 16 & 53.3 \\
& & 46.7 \\
Less is better & 14 & 100,0 \\
Total & 30 & \\
\hline
\end{tabular}

The table above shows that the respondents who have good family support as many as 16 people (53.3\% of) and which has the support of the family is less well as many as 14 people $(46,7 \%)$.

Table 2. Frequency distribution of Respondents Based on the Activeness of $(n=30)$

\begin{tabular}{ccc}
\hline Liveliness & Number & $\%$ \\
\hline Active & 11 & 36,7 \\
Not active & 19 & 63,3 \\
Total & 30 & 100,0 \\
\hline
\end{tabular}

The table above shows that the respondents who activeness categorized as many as 11 people $(36,7 \%)$ and are not as active as many as 19 people (of $63.3 \%$ ).

Table 3. Analysis of the Relationship of Family Support with the Liveliness of Following the exercises In Patients with Diabetes Mellitus Type Two In the Club Prolanis Diamen Barigas BPJS Office Palangka Raya May 2018 (n=30)

\begin{tabular}{cccccccc}
\hline Family Support & \multicolumn{7}{c}{ Liveliness } \\
& \multicolumn{1}{c}{ Active } & Not Active & \multicolumn{2}{c}{ Total } & p-value \\
& $\mathrm{f}$ & $\%$ & $\mathrm{~F}$ & $\%$ & $\mathrm{f}$ & $\%$ & \\
& 9 & 56,2 & 7 & 43,8 & 16 & 100 & \\
\hline Good & 2 & 14,3 & 12 & 85,7 & 14 & 100 & 0,046 \\
Less Is Better & & & & & & & \\
Total & 11 & 36,7 & 19 & 63,3 & 40 & 100 & \\
\hline
\end{tabular}

The table above shows that as many as 16 respondents who support his family better, is composed of 9 respondents or (of 56.2\%) who actively participated in gymnastics and 7 respondents $(43,8 \%$ ) who did not actively participate in gymnastics, while 14 respondents who support his family is not good, is composed of 2 respondents (14.3 percent) who actively participated in gymnastics and 12 respondents $(85.7 \%$ of) respondents who did not actively participate in gymnastics, through the results of the statistical test continuity correction is known that the significance value $p$ value 0,046 , because the $p$-value $<\alpha(0.05)$ this means that $\mathrm{Ho}$ is rejected and $\mathrm{Ha}$ accepted, it can be concluded that there is a significant relationship https://ijhp.net 
between family support with the liveliness of following the exercises in patients with diabetes mellitus type two In the Club Prolanis Diamen Barigas BPJS Office Palangka Raya.

\section{DISCUSSION}

This study showed no significant relationship between family support with the liveliness of following the exercises in patients with diabetes mellitus type two In the Club Prolanis Diamen Barigas BPJS Office Palangka Raya. This can be evidenced from the results of the study that out of 16 respondents belongs to the category of good family support consists of 9 people with the category of liveliness active, and 7 people with the category of liveliness is not active in participating in gymnastics. Then for the 14 respondents that belongs to the category of family support less well consists of 2 people with the category of the liveliness of an active and 12 people with the category is not active in participating in gymnastics. See from the results of the respondents who have the category of family support less well most of the features category of the liveliness is not active in participating in gymnastics, this is due to the family not provide support to patients with DM, busy because of work, and attitude of diabetic patients are still lacking adhere to the schedule of gymnastics has been determined.Previous research Siregar (2017) stated the relationship of knowledge, attitude, and family support to the liveliness of patients with type 2 Diabetes Mellitus to follow the activities of Prolanis in the Working Area of Puskesmas Kertek I Kabupaten Wonosobo.

The results of this study are also in line with the results of previous studies. Satriana (2013) conducted a study on the respondents of the elderly showed that there is a relationship between family support with the liveliness of gymnastics in elderly Posyandu Wijaya Kusuma Bambanglipuro Bantul Yogyakarta. Another study conducted by Subari (2008), researching about "the Relationship Between Family Support With the Liveliness of Patients with Diabetes Mellitus In the Following Gymnastics Diabetes Mellitus In the Hospital Dr. Oen Solo Baru“.This study concluded that there is a relationship between family support with the liveliness of patients with Diabetes Mellitus in participating in gymnastics at the Club Diabetes Mellitus Hospital Dr. Oen Solo Baru. Agustiana (2016) also conducted a study on the respondents diabetes mellitus type two to see family support compliance with physical exercise, from these results that the presence of meaningful relationships (significant) between family support with the compliance of physical exercise in patients with DM type two in RSUD Tugurejo. The theory also said family support is an attitude, action and acceptance of the family on the ill patient.

Family members perceive that people who are support always ready to provide aid and assistance if needed (Friedman 1998). The family serves as a support system for its members. The support of the people which are connected by ties of marriage (husband/wife), birth (of a child), and adobsi will create and maintain the culture of a common patient, enhance the development of physical, mental, emotional and social. Such support can be done by: 1) Support information: includes the provision of advice, suggestions and information; 2) Support the assessment: include guidance feedback, guide and mediate the breakdown of the problem, as the source and validator identity of family members rooms even provide the support, appreciation, attention; 3) instrumental Support: include a source of aid practical and concrete, including the health of the patients in terms of the need to eat and drink, rest, avoiding patients fatigue; 4) emotional Support: includes support which is manifested in the form of affection, trust, attention, listened and listened (Friedman 2008). The family is the primary support system in maintaining health.

The role of the family in the care of, among others, maintain or care for, maintain and improve the mental status, support and socio-economic changes, as well as provide motivation, support and facilitate your spiritual needs. When high family support will then be able to reduce morbidity and numbers death that will ultimately improve the quality of life of patients with Diabetes Mellitus . In addition, the presence of family support for patients with diabetes mellitus can improve physical health, management, reaction to stress, productivity, and psychological well-being and the ability of self-adjustment of patients with diabetes mellitus (Sumardi, 2016). A good family support will provide support and motivation for patients with diabetes mellitus to do as well as maintaining the condition of patients with diabetes mellitus in order to remain stable, one of them is to run the management of diabetes mellitus namely sports (gymnastics). According to (Darmojo:2009 in Satriana 2013) a workout or sports such as gymnastics can eliminate the risk 
of various diseases such as hypertension, diabetes mellitus, and coronary artery disease. The pattern of the relationship of family support with the liveliness of the show that the higher the support of the family, then the higher the liveliness of patients with diabetes mellitus in doing gymnastics. On the contrary the lower support of the family, the lower the activity level of patients with diabetes mellitus in doing gymnastics.

\section{CONCLUSION}

Through the results of the research that has been conducted in Club Prolanis Diamen Barigas BPJS Office Palangka Raya can be concluded that from a total of 30 respondents, the number of respondents with good family support amounted to 16 respondents $(53,3 \%)$, and respondents with the level of family support less well were 14 respondents (46,7\%). Respondents are included in the category active to follow the gymnastics of a total of 11 respondents $(36,7 \%)$ and did not actively participate in gymnastics amounted to 19 respondents (of 63.3\%).

The results of the analysis using a statistical test continuity correction is known that the significance value $\mathrm{p}$ value 0,046 , because the $\mathrm{p}$-value $<\alpha(0.05)$ it means that Ho is rejected and Ha is accepted, it can be concluded that there is a significant relationship between family support with the liveliness of following the exercises in patients with diabetes mellitus type two In the Club Prolanis Diamen Barigas BPJS Office Palangka Raya.

\section{REFERENCES}

[1] Agustiana, Mika. 2016. Hubungan Antara Dukungan Keluarga Dengan Kepatuhan Latihan Jasmani Pada Pasien Diabetes Mellitus Tipe 2 Di Rsud Tugurejo . (Online), (https://anzdoc.com/hubungan-antara-dukungankeluarga-dengan-kepatuhan-latihan-j.html) diakses 25 mei 2018

[2] Bustan. (2007). Epideminologi Penyakit Tidak Menular. Jakarta: PT Rineka Cipta

[3] Dinas Kesehatan Provinsi Kalimantan Tengah. Jumlah Kasus 10 Penyakit Terbanyak di Provinsi Kalimantan Tengah. 2015. (Online), (http://bappeda.kalteng.go.id/satudata/tabel/index/109/back_2), diakses 29 november 2017

[4] Data Informasi Kesehatan. Penyakit Tidak Menular. 2012.

(Online), (http://www.depkes.go.id/folder/view/01/structure-publikasi-pusdatin-buletin.html), diakses 17 Desember 2017

[5] Eko. (2011). Hubungan Antara Dukugan Keluarga Dengan Keikutsertaan Senam Lansia Di Perumahan Sinar Waluyo Semarang. Jurnal Keperawatan, (Online),

4 (2) : 121-132,(http://jurnal.unimus.ac.id/index.php/FIKkeS/article/view/1849/1891), diakses tanggal 03 desember 2017

[6] Friedman. 1998. Keperawatan Keluarga. Jakarta : EGC.

[7] Friedman, M. M. 2008. Keperawatan Keluarga Teori dan Praktik. Jakarta: EGC.

[8] Ilyas, E.I. (2009). Penatalaksanaan Diabetes melitus Terpadu. Jakarta: FKUI

[9] Perkeni. Konsensus Pengelolaan Dan Pencegahan Diabetes Melitus Tipe 2 Di Indonesia. 2015. (Online), (http://pbperkeni.or.id/doc/konsensus.pdf) . diakses 25 november 2017

[10] Pusat Data dan Informasi kesehatan RI.. Infodatin diabetes.

2014. (Online), (http://www.depkes.go.id/resources/download/pusdatin/infodatin/infodatin-diabetes.pdf), diakses 04 november 2017

[11] Siregar, Fithri Mubraroh. (2017). Faktor-Faktor Yang Mempengaruhi Keaktifan Penderita Diabetes Melitus Tipe 2 Mengikuti Kegiatan Prolanis Di Wilayah Kerja Puskesmas Kertek I Kabupaten Wonosobo. (Online), (http://perpusnwu.web.id/karyailmiah/documents/5413.pdf), diakses 04 desember 2017

[12] Subari , N.D. 2008. "Hubungan Antara Dukungan Keluarga Dengan Keaktifan Penderita Diabetes Mellitus Dalam Mengikuti Senam Di Klub Senam Diabetes Mellitus Rumah Sakit Dr. Oen Solo Baru". (Online),(Http://Eprints.Ums.Ac.Id/2713/1/J220060049.Pdf), diakses 25 Mei 2018.

[13] Satriana, Nova. (2013). Hubungan Dukungan Keluarga Dengan Keaktifan Senam Lansia Di Posyandu Wijaya Kusuma Bambanglipuro Bantul Yogyakarta. (Online), (http://repository.stikesayaniyk.ac.id/847/1/Nova\%20Satriana_32115015_nonfull.pdf), diakses 03 desember 2017 
[14] Sumardi. (2016). Gambaran Dukungan Keluarga Terhadap Ibu Hamil Dengan Hiperemesis Gravidarum. (Online),(http://repository.umy.ac.id/bitstream/handle/123456789/2776/BAB\%20II.pdf?sequence=6\&isAllowed $=\mathrm{y})$, diakses 09 desember 2017

[15] Sukardji, Kartini. (2009). Penatalaksanaan Diabetes melitus Terpadu. Jakarta: FKUI

[16] Vivin Novarina. (2012). Hubungan Dukungan Keluarga Tentang Senam Lansia Dengan Keaktifan Mengikuti Senam Di Posyandu "Peduli Insani" Di Mendungan Desa Pabelan Kartasura. (Online), (Http://Eprints.Ums.Ac.Id/20154/9/Naskah_Publikasi.Pdf), diakses 07 Desember 2017

[17] Waspaji, S. (2009). Penatalaksanaan Diabetes Melitus Terpadu. Jakarta: FKUI

[18] WHO. Diabetes Fakta Dan Angka. 2016. (Online),

(http://www.searo.who.int/indonesia/topics/ino-whd-2016-campaign/en/), diakses 17 Desember 2017 